\title{
A POORLY KNOWN RODENTLIKE MAMMAL (PACHYRUKHINAE, HEGETOTHERIIDAE, NOTOUNGULATA) FROM THE DESEADAN (LATE OLIGOCENE) OF ARGENTINA. PALEOECOLOGY, BIOGEOGRAPHY, AND RADIATION OF THE RODENTLIKE UNGULATES IN SOUTH AMERICA
}

\author{
MARCELO A. REGUERO,${ }^{1}$ MARÍA TERESA DOZO,${ }^{2}$ AND ESPERANZA CERDEÑO ${ }^{3}$ \\ 'División Paleontología de Vertebrados, Museo de La Plata, B1900FWA La Plata, Argentina, <regui@ @cnym.unlp.edu.ar>, ${ }^{2}$ Laboratorio de Paleontología, \\ Centro Nacional Patagonico, Consejo Nacional de Investigaciones Cientificas y Técnicas, 9120 Puerto Madryn, Chubut, Argentina, <dozo@cenpat.edu.ar>, \\ and ${ }^{3}$ Departamento de Geología y Paleontología, Instituto Argentino de Nivología, Glaciología, y Ciencias Ambientales, Centro Regional de Investigaciones \\ Científicas y Técnicas, Consejo Nacional de Investigaciones Científicas y Técnicas, Avda. Ruiz Leal s/n, 5500 Mendoza, Argentina, <espe@lab.cricyt.edu.ar>
}

\begin{abstract}
The cranial anatomy of the Deseadan species Medistylus dorsatus (Ameghino, 1903) is described based on new and complete material from Cabeza Blanca (Chubut, Argentina). Medistylus is the largest of the Pachyrukhinae and the specimen described here is probably the best-preserved pachyrukhine skull known in the Paleogene of South America. Previously, the validity of the species and its phylogenetic affinities with Interatheriidae (Notoungulata, Typotheria) were ambiguous and not conclusive. The syntypes, now reported lost, were isolated teeth poorly described by Ameghino in 1903. This almost complete skull with teeth provides more diagnostic features in order to complete the knowledge of genus. Details about cranial and dental morphology allow the reassessment of Medistylus dorsatus and its inclusion within the subfamily Pachyrukhinae (Hegetotheriidae, Notoungulata). Its cranial and dental specializations and the apparent sympatry with its close relatives Prosotherium garzoni Ameghino, 1897 and Propachyrucos smithwoodwardi Ameghino, 1897 all imply a narrow niche partitioning among the Pachyrukhinae during the Deseadan (late Oligocene). The occurrence of three euhypsodont genera of Pachyrukhinae in the Deseadan of Patagonia reflects the major radiation of the rodentlike ungulates in the Cenozoic of South America and suggests a great paleoenvironmental difference between the late Oligocene faunas of Patagonia and those from Bolivia and Uruguay, where they did not live.
\end{abstract}

\section{INTRODUCTION}

$\mathrm{D}^{2}$ URING THE early and middle Cenozoic, the notoungulates were the most successful and diverse ungulate group that lived in South America (Patterson and Pascual, 1972; Reig, 1981; Bond, 1986; Cifelli, 1985, 1993; Marshall and Cifelli, 1989; Croft, 1999). They experienced a broad adaptive radiation including small rodent- (Interatheriidae) and rabbitlike (Hegetotheriidae) forms and medium to great-sized tapir- (Isotemnidae) and rhinolike (Toxodontidae) forms.

Two hegetotheriid sub-groups are generally recognized (Simpson, 1945a; McKenna and Bell, 1997): Hegetotheriinae and Pachyrukhinae. Pachyrukhinae is universally considered monophyletic (Cerdeño and Bond, 1998) and the clade is certainly recognizable as early as the Deseadan (Loomis, 1914; Simpson, 1945a; Dozo et al., 2000) and potentially as early as the Tinguirirican (Reguero, 1993). In contrast, Hegetotheriinae is likely paraphyletic, though it may include a monophyletic subset of Miocene taxa (Cifelli, 1993; Croft, 2000; Croft and Anaya, 2004; Croft et al., 2004).

The Pachyrukhinae are small terrestrial herbivorous Hegetotheriidae (Notoungulata) easily recognized by their specialized anterior dentition, "rabbit-like" and evergrowing (rootless) incisors and cheek teeth. They were extremely abundant in the mid-Cenozoic of Argentina. Based on dental dimensions, their body size would have ranged from 1.8 to $2.2 \mathrm{~kg}$ (Castro, 2001); it is interesting to note that the only extant ungulate with similar size is the ruminant Asian tragulid mouse deer, the smallest artiodactyl known.

The Pachyrukhinae show remarkable convergence with the caviomorph rodents; their closest ecological analog would be the living Dolichotis patagonum (Zimmermann, 1780) ("mara"), a large cursorial Patagonian rodent, which resembles pachyrukhines in skull morphology and pedal adaptations. Dozo (1997), based on a paleoneurologic study, concluded that the convergence of these mammals, currently established on the basis of dental and postcranial features, is also shown in the superficial neuromorphology.

The biochron of the subfamily Pachyrukhinae ranges from the early Oligocene Tinguirirican South American Land Mammal
Age (SALMA) (Reguero, 1999) to the late Pliocene-early Pleistocene? (Marplatan, Ensenadan? ages). Representatives of this subfamily are well known from the Deseadan SALMA of Patagonia with the genera Prosotherium Ameghino 1897 and Propachyrucos Ameghino 1897 (Simpson, 1945b).

Medistylus Stirton 1952 has been an enigmatic notoungulate and source of confusion for over a century. Florentino Ameghino (1903) erected the genotypic species based upon three upper molars, and placed it under the preoccupied name Phanophilus Ameghino 1903, within the Interatheriidae (his own family Protypotheridae). Ameghino compared Phanophilus dorsatus Ameghino 1903 with the hegetotheriid Prosotherium garzoni Ameghino 1897 (Pachyrukhinae), remarking their resemblances, but still placing it within the Interatheriidae. Based on the drawing of Ameghino, Loomis (1914:74) recognized and described a second occurrence of Phanophilus dorsatus from Cabeza Blanca. Loomis concluded that Medistylus is a Hegetotheriidae, but stated that the position of the genus "is uncertain." Stirton (1952) renamed the genus as Medistylus regarding it as an interatheriid, and so was accepted by the subsequent reviewers.

In 2001, after more than 100 years, a new specimen of a small hegetotheriid was discovered in the same locality. The discovery of a nearly complete skull at Cabeza Blanca, southeast of the Chubut Province $\left(45^{\circ} 13.55^{\prime} \mathrm{S}, 67^{\circ} 28.07 \mathrm{~W}\right)$ (Fig. 1) has allowed us to refer it to Medistylus dorsatus (Ameghino,1903), increasing the knowledge of this species and providing a more nearly complete diagnosis. The morphological information as revealed by this specimen improves our understanding of the systematics and functional morphology of this group.

The fossiliferous site of Cabeza Blanca belongs to the Sarmiento Formation (Spalletti and Mazzoni, 1979), San Jorge Basin. It is one of the richest and most important fossil vertebrate localities of the Paleogene of Argentina and was discovered by Carlos Ameghino over 110 years ago (Ameghino, 1897). He recovered abundant remains of both Deseadan (late Oligocene) and Barrancan "Casamayoran" (late Eocene) mammals. The Sarmiento Formation is subdivided into three members: Gran Barranca Member (late Eocene), Puesto Almendra Member (late Eocene-late Oligocene), and Colhue Huapi Member (early Miocene). 


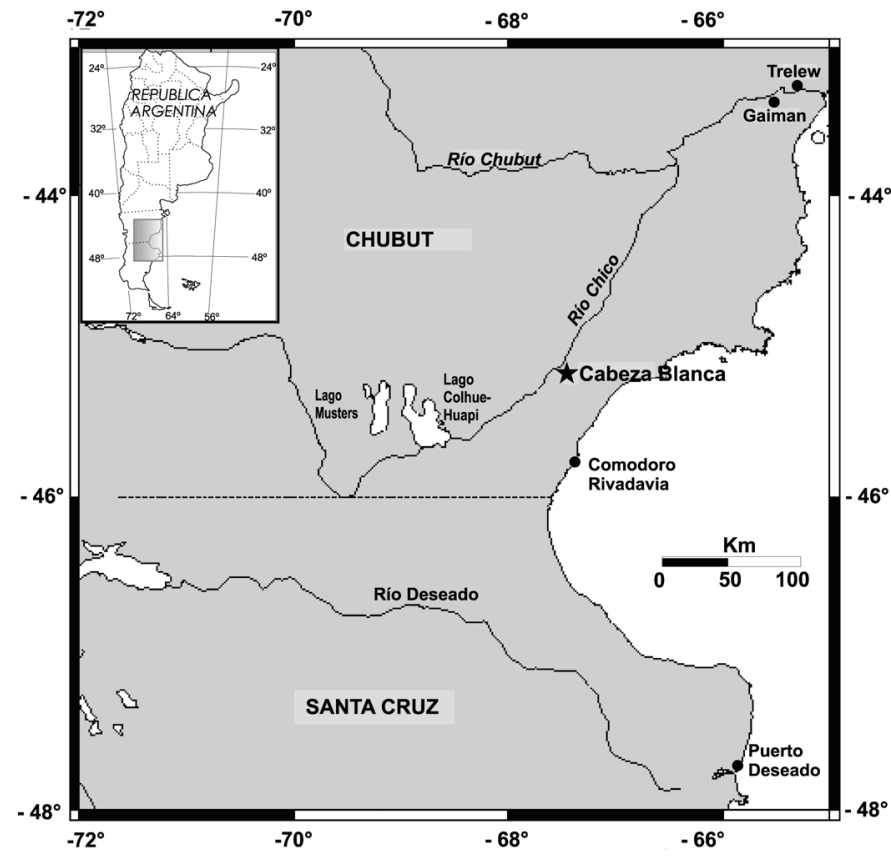

Figure 1-Geographic location of the fossiliferous outcrop at Golfo de San Jorge Basin, in the Chubut Province, Argentina.

At Cabeza Blanca, the fossils occur in pedogenically altered volcaniclastic mudrock, silt, sand, and granular intraclastites interbedded with four to eight layers of relatively pure volcanic ash. Most of the Deseadan sequence is preserved in a strike valley that cuts unconformably into dipping nonresistant, pink volcanic mudrock that yields Barrancan mammals. Nearshore and shallow marine rocks of the basal part of the of the Miocene "Patagonian" overlie Deseadan channel fill in depositional lows and drape and pinch out over highs in the post-Deseadan paleotopography.

\section{MATERIALS AND METHODS}

The specimen of Pachyrukhinae described in this paper (MPEF-PV 693, incomplete skull preserving the complete upper dental series) was collected at Cabeza Blanca, southeast of the Chubut province $\left(45^{\circ} 13.55^{\prime} \mathrm{S}, 67^{\circ} 28.07 \mathrm{~W}\right)$, Argentina, in 1993, and is housed at the Museo Paleontológico "Egidio Feruglio" in Trelew, Argentina.

The systematic study has been based on morphometric comparison with other known Deseadan pachyrukhines. Special emphasis has been put on the crown height of the molars and the width of the muzzle. The hypsodonty index is probably the best single variable for predicting diet in both extant and extinct ungulates (Janis, 1988, 1995; Pérez-Barberia and Gordon, 2001). Also, these two characters have been recognized in diverse mammal groups as good evidence of paleoenvironmental adaptations concerning diet (Janis, 1988; Janis et al., 2000; Williams and Kay, 2001).

The relative crown height or hypsodonty is measured by the Hypsodonty Index (HI), dividing the crown height $(\mathrm{H})$ by the anteroposterior length (APL). $\mathrm{H}$ is measured along the paracone ridge, and APL is taken along the ectoloph at the occlusal surface (Shockey, 1997). Hypsodonty is assumed to be a response to increased dental wear, mainly due to more abrasive herbivorous diets (Janis, 1995).

The relative width of the muzzle (RWM) is determined by the ratio of the palatal width (PAW) to the muzzle width (MZW) (Janis and Ehrhardt, 1988). PAW is the distance between the lingual borders of the protocones on the opposite M2s, and MZW is the width of the snout at the premaxilla-maxilla border. PSI is the Premaxillary Shape Index used by Dompierre and Churcher (1996). In animals having snouts that become broader anterior to the premaxilla-maxilla boundary, the greatest width of the premaxilla is measured (Shockey, 1997).

Abbreviations.-The following acronyms are used to refer to institutional repositories of specimens: ACM, Amherst College Museum, Amherst, Massachusetts, USA; MACN, Museo Argentino de Ciencias Naturales "Bernardino Rivadavia," Buenos Aires, Argentina; MLP, Museo de La Plata, La Plata, Argentina; MPEF, Museo Paleontológico "Egidio Feruglio," Trelew, Argentina.

Key to abbreviations used in Figure 2 for anatomical structures: I1, first upper incisor; I2, second upper incisor; P1, first upper premolar; M1, first upper molar; na, nasal; zy pl, zygomatic plate.

\section{SYSTEMATIC PALEONTOLOGY}

Class Mammalia Linnaeus, 1758

Order Notoungulata Roth, 1903a

Suborder TYPOTHERIA Zittel, 1893

(Reguero and Castro, 2004)

Family HEGETOTHERIIDAE Ameghino, 1894

Subfamily PACHYRUKHINAE Kraglievich, 1934

(see diagnosis in Cerdeño and Bond, 1998)

Genus Medistylus Stirton, 1952

Type species.-Phanopylus dorsatus Ameghino, 1903, by original designation; late Oligocene, Deseadan SALMA, Chubut Province, Argentina.

Diagnosis.-Compared to Prosotherium and Propachyrucos: size average about 5\% larger than Prosotherium and $10 \%$ than Propachyrucos. I1 deeply and obliquely implanted and enlarged, but less than in Prosotherium. The incisors form a selective foodcropping mechanism different from the rest of the species of $\mathrm{Pa}$ chyrukhinae. Diastema between I2 and P1 longer than in Prosotherium. Upper molars narrower than in Prosotherium. Mesostyle present on the ectoloph of upper molars. More robust muzzle and orbits more laterally expanded than in Propachyrucos and Paedotherium.

At present, the genus contains only the type species, Medistylus dorsatus.

Occurrence.-Patagonia, Chubut Province, Argentina. Deseadan SALMA (late Oligocene).

\section{MEDISTYLUS DORSATUS \\ (Ameghino, 1903)}

Figure 2

Diagnosis.-As for the genus.

Description.-The skull of Medistylus dorsatus (MPEF-PV 693) belongs to an adult individual with worn teeth. Some of the sutures between bones have been obliterated, but the skull is complete except for some areas in the

TABLE 1-Dental measurements of the upper dentition of Medistylus dorsatus (mm).

\begin{tabular}{|c|c|c|c|c|c|c|c|c|c|c|c|c|c|c|}
\hline & \multicolumn{2}{|c|}{$\mathrm{P} 1$} & \multicolumn{2}{|c|}{$\mathrm{P} 2$} & \multicolumn{2}{|c|}{ P3 } & \multicolumn{2}{|c|}{$\mathrm{P} 4$} & \multicolumn{2}{|c|}{ M1 } & \multicolumn{2}{|c|}{ M2 } & \multicolumn{2}{|c|}{ M3 } \\
\hline & $\mathrm{AP}$ & TR & AP & $\mathrm{TR}$ & $\mathrm{AP}$ & $\mathrm{TR}$ & $\mathrm{AP}$ & TR & $\mathrm{AP}$ & TR & $\mathrm{AP}$ & TR & $\mathrm{AP}$ & TR \\
\hline MPEF-PV 693 & 3.1 & 2.3 & 4.3 & 2.4 & 4.7 & 3.1 & 4.5 & 3.1 & 5.4 & 3.1 & 4.8 & 3.4 & 5.3 & 3.2 \\
\hline MPEF-PV 1655 & - & - & - & - & - & - & - & - & 5.7 & 3.5 & - & - & - & - \\
\hline MLP 93-XI-21-19a & - & - & - & - & - & - & - & - & $? 5.6$ & 3.4 & 5.6 & 3.6 & 5.6 & 3.5 \\
\hline $\mathrm{ACM} ?$ & - & - & - & - & - & - & - & - & - & - & - & - & 5.5 & 3.7 \\
\hline
\end{tabular}



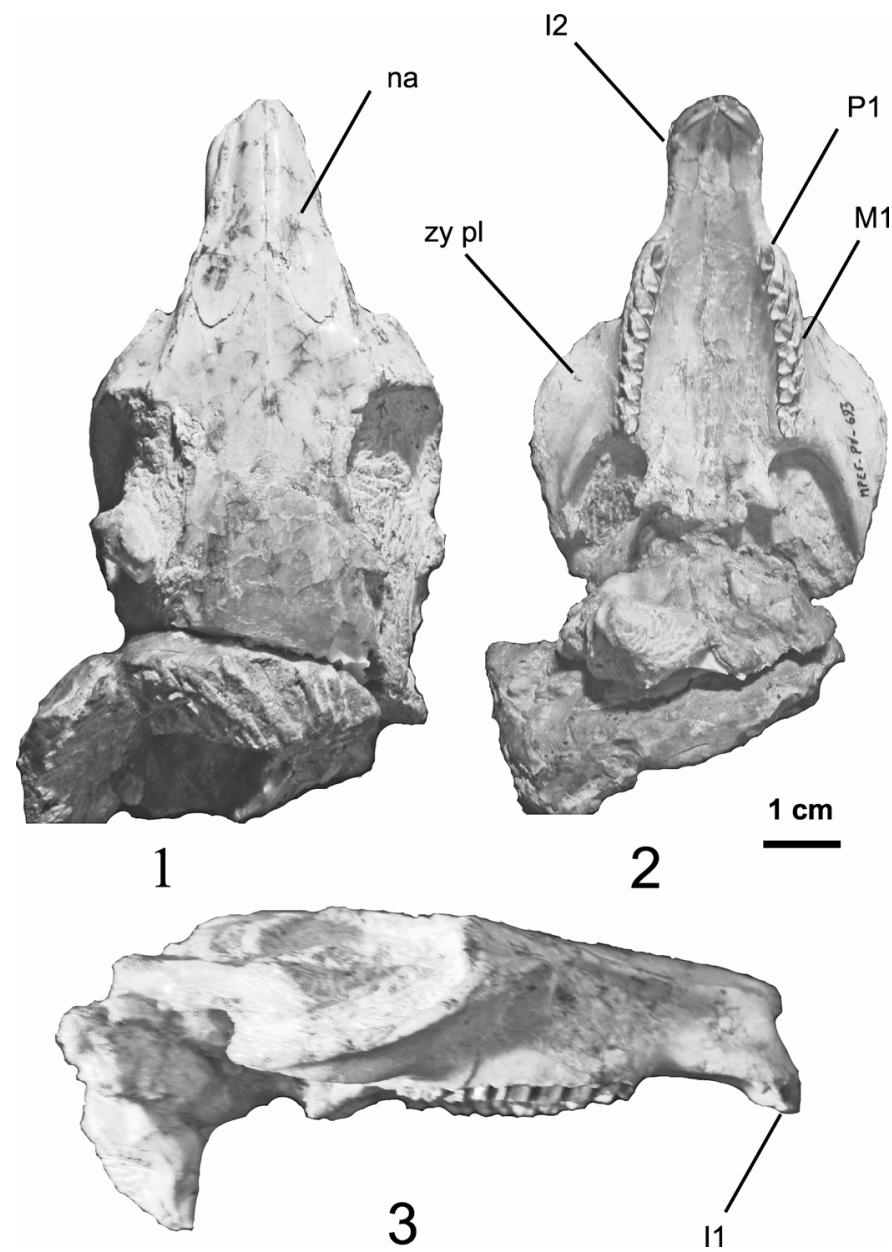

FIGURE 2-Skull of Medistylus dorsatus (Ameghino, 1903), referred specimen MPEF-PV 693, in lateral (1), dorsal (2), and ventral (3) views.

caudal portion of the skull roof, in particular the caudodorsal part of the squamosals, the supraoccipital, and the posterior part of the zygomatic arches. The maximum length and width of the skull are $93.0 \mathrm{~mm}$ and $55.4 \mathrm{~mm}$, respectively. The palate is $20.28 \mathrm{~mm}$ between M2s. The distance between left and right zygomatic arches is $55.5 \mathrm{~mm}$. It roughly resembles a larger version of Prosotherium garzoni, a Deseadan pachyrukhine described in some detail by Loomis (1914:73, fig. 41). The incisors and long diastema between I2 and P1 make the snout relatively longer than in P. garzoni (Fig. 3). Miocene and Pliocene Pachyrukhinae show a narrower rostrum than Medistylus and Prosotherium.

I1 is enlarged, curved, rootless, and deeply implanted. A thick layer of cementum covers the labial face of the tooth. I2, only preserved on the right side, is a small and cylindrical tooth. It is completely attached to the posterior face of the I1. There is a long diastema between I2 and P1.

The cheek teeth are evergrowing and encased by thick external cementum. The premolar sequence increases gradually in size from P1 to P4 (Fig. 4). The P2-4 are all obliquely imbricated and subtriangular in shape. The lingual faces of these premolars are somewhat flattened and are very similar to those of Pachyrukhos Ameghino, 1885. The ectoloph is very smooth with a shallow paracone/parastyle groove.

M1-2 are longer than wide and have a deep and narrow lingual sulcus separating two lobes, the anterior lobe smaller than the posterior one. The sulcus persists throughout the height of the crown. The anterior lobe of M12 is triangular in outline and the posterior one is more quadrangular. A strong and sharp mesostyle is also present throughout the height of the ectoloph. M3 is very similar, but with a less developed mesostyle; in contrast, it has a posteriorly projecting metastyle.

Lower molars are presently unknown for this species.

Type--Syntypes, MACN A52-488, three upper molars, probably of the same individual. Patterson (1952) selected as lectotype the specimen figured by Ameghino (1904:88, fig.92). The syntypes have not been found within the Ameghino Collection of the MACN; there is no evidence of any researcher

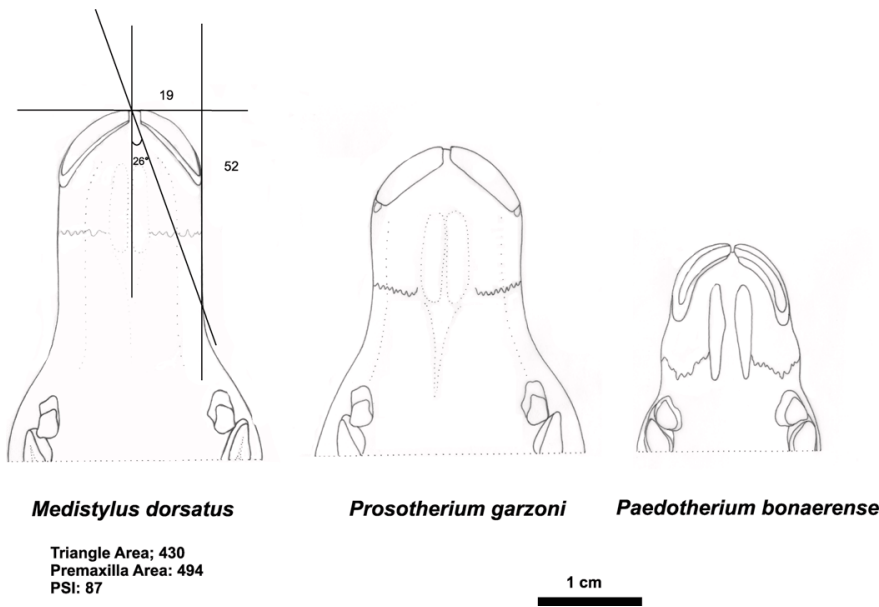

FIGURE 3-Outlines of premaxillae, in ventral view, of three pachyrukhines: Medistylus dorsatus (1), Prosotherium garzoni Ameghino, 1897 (2), and Paedotherium bonaerense (Ameghino, 1887b) (3). PSI calculated for Medistylus dorsatus.

having studied them since 1903, and they have recently been reported lost (Reguero, 1999).

Material examined.-MLP 93-XI-21-19, right maxillary fragment with M1-3, MPEF-PV 693, incomplete skull preserving the complete right and left upper series, and MPEF-PV 1655, one upper right molar.

Occurrence.-Sarmiento Formation, late Oligocene, Deseadan SALMA. MACN A52-488 is of uncertain provenance (labeled "Crétacé le plus supérieur de Patagonie [Pyrothéréen]" of Ameghinos usage), but it probably comes from Cabeza Blanca (Chubut). MPEF-PV 693 and MPEF-PV 1655 come from Cabeza Blanca (Chubut) and MLP 93-IX-21-19 comes from Las Cascadas (Chubut).

Discussion.-The genus Medistylus was inadequately known, mainly due to the scarcity of the material referred to it. The type of Medistylus dorsatus, MACN A52-488, includes three upper molars, presently lost. Ameghino (1904, fig. 92 a, b) figured one of them in occlusal and labial views, and identified this tooth as a right upper molar, probably M1 or M2. Stirton (1952: 351) changed the name Phanophilus to Medistylus, adding that it is "one of the smallest interatheres known from the Deseado late

\section{Medistylus Prosotherium Pachyrukhos Paedotherium}
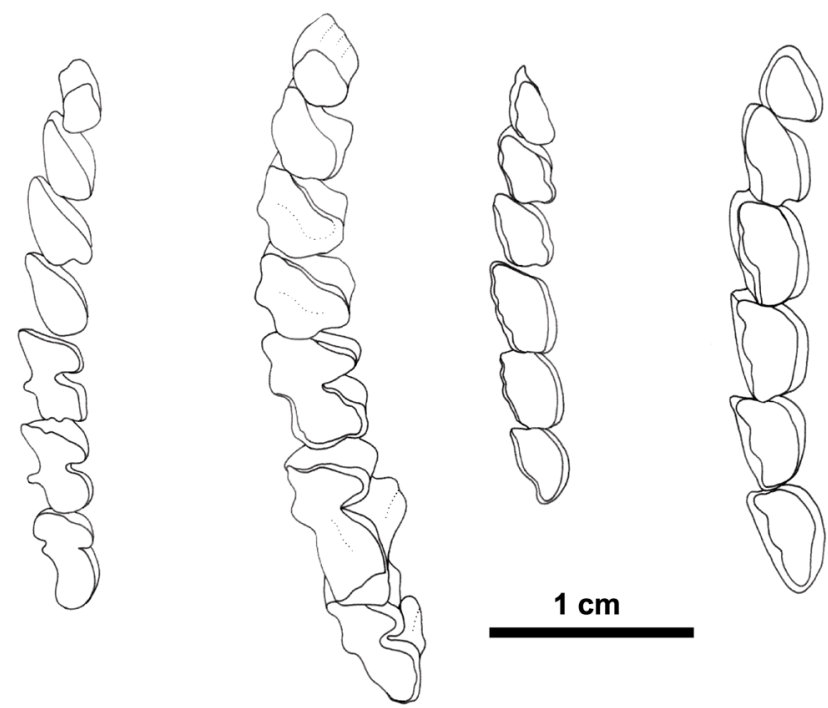

FIGURE 4-Right upper dental series of pachyrukhines, occlusal views: Medistylus dorsatus, P1-M3, Prosotherium garzoni, P1-M3, Pachyrukho moyanoi Ameghino, 1885, P2-M3, and Paedotherium bonaerense, P2-M3. 
TABLE 2-Calculation of relative muzzle/palatal width ratios and Hypsodonty Index for small/medium-sized Oligocene/Pliocene typothere species.

\begin{tabular}{|c|c|c|c|c|}
\hline Species & MZW & PAW & RMW & $\mathrm{HI}$ \\
\hline \multicolumn{5}{|l|}{ Hegetotheriidae } \\
\hline Prohegetotherium sculptum (Ameghino, 1897) & - & - & - & 2.23 \\
\hline Hegetotherium mirabile (Ameghino, 1887a) & 17.1 & 24.0 & 1.40 & 2.42 \\
\hline Prosotherium garzoni (Ameghino, 1897) & 16.5 & $\sim 19.3$ & 1.70 & 2.72 \\
\hline Pachyrukhos moyanoi (Ameghino, 1885) & 11.2 & 15.8 & 1.41 & 3.52 \\
\hline Tremacyllus impressus (Ameghino, 1888) & 4.5 & 6.3 & 1.40 & 3.23 \\
\hline Paedotherium bonaerense (Ameghino, 1887b) & 15.5 & 18.0 & 1.56 & 4.06 \\
\hline Protarchaeohyrax gracilis (Roth, 1903) & 10.26 & $\sim 14.4$ & 1.40 & 1.73 \\
\hline Archaeohyrax patagonicus (Ameghino, 1897) & 23.0 & 34.5 & 1.50 & 2.74 \\
\hline \multicolumn{5}{|l|}{ Interatheriidae } \\
\hline Protypotherium australe (Ameghino, 1887c) & 20.9 & 24.2 & 1.15 & 2.34 \\
\hline Interatherium rodens (Moreno, 1882) & 12.3 & 17.6 & 1.43 & 2.94 \\
\hline
\end{tabular}

Oligocene of Argentina." No author published any further considerations about this genus.

The studied skull allows us to establish that the dental morphology of Medistylus is similar to that of the Deseadan Pachyrukhinae Propachyrucos and Prosotherium, and to place the former within Pachyrukhinae, as we previously indicated (Dozo et al., 2000). These three genera share non-molariform premolars and a deep lingual sulcus on the molars. Cifelli (1993) and Reguero (1999) have regarded the similarity of the molars of $\mathrm{Pa}$ chyrukhinae and Interatheriidae as a process of convergence.

Medistylus differs from Prosotherium in having narrower molars and a strong mesostyle on the upper molars (Fig. 4). With respect to Propachyrucos, Medistylus differs by the presence of a diastema between I 2 and P1 and by its overall robustness and greater size.

The clade comprised by Medistylus, Prosotherium, and Propachyrucos has been diagnosed by at least two synapomorphies: deep lingual sulcus on M1-3 and non-molariform premolars (Cifelli, 1993; Reguero, 1999; Castro, 2001). Medistylus dorsatus shares features such as a robust and long snout, a great expansion of the zygomatic arch, and a great development of the zygomatic plate with its sister species Prosotherium garzoni, which prompted the placement of these two species apart from Propachyrucos smithwoodwardi Ameghino,1897 (Castro, 2001).

With the recognition of Medistylus dorsatus as a Pachyrukhinae, we conclude that the major diversification of the clade (three genera and three species) is recorded in the Deseadan SALMA of Patagonia.

\section{PALEOECOLOGY AND RADIATION OF THE RODENTLIKE PACHYRUKHINAE IN SOUTH AMERICA}

Janis $(1988,1997)$ assumed that dental morphology is sufficiently plastic in evolution that it reflects the diet of the animal rather than merely its taxonomic affiliation. According to Williams and Kay (2001), diet can be reasonably inferred from dental morphology, based on the correlation of dietary types with tooth morphology in living ungulates and rodents. The timing and adaptive significance of the rise of the hypsodonty in South American ungulates, and in general among mammalian herbivores, are poorly understood; whether hypsodonty reflects a coevolutionary response to the evolution of silica phytoliths in plants or to increases in exogenous dietary grit or a combination of both factors is not resolved (Pascual et al., 2002). The grass phytolith record indicates increases in diversity and abundance of grasses since the Late Eocene (Strömberg, 2002). Kay et al. (1999) considered the appearance of the high crowned South American ungulates (between $36 \mathrm{Ma}$ and before $32 \mathrm{Ma}$ ), especially the typotheres, coincides with a trend of cooling of the ocean surface temperatures in the Southern Hemisphere (between 36 and $33 \mathrm{Ma}$ ). In contrast,
Kohn et al. (2004) proposed that fossil mammal teeth from midlatitude southern Argentina $\left(46^{\circ} \mathrm{S}\right)$ closely bracketing the EoceneOligocene transition show no resolvable change in oxygen isotope composition. In combination with paleofloral observations and geographic considerations, this finding implies not only that climate was essentially constant, despite interpretations elsewhere for major mid- and high-latitude cooling, but also that evolution of hypsodonty did not coincide with climate change during the Eocene-Oligocene transition. In southern Argentina, the initiation of hypsodonty occurred between 39.3 and $38.0 \mathrm{Ma}$, prior to the Eocene-Oligocene transition.

The Deseadan Pachyrukhinae show very marked "rodentlike" adaptations and have been also considered as ecological equivalents of certain rodents and lagomorphs. Most small- to mediumsized typotheres in the Deseadan of Patagonia show very highcrowned (hypsodont to hypselodont) cheek teeth (Table 2). Only few advanced typotheres (Notoungulata) like Archaeohyracidae (Reguero, 1999), Interatheriidae (Hitz et al., 2000, Reguero et al., 2002), and Mesotheriidae Trachytheriinae (Reguero and Castro, 2004) parallel Pachyrukhinae in hypsodonty. However, the $\mathrm{Pa}$ chyrukhinae constitute the most hypselodont clade (with evergrowing cheek teeth) among Deseadan notoungulates, even more than coeval primitive Archaeohyracidae, Mesotheriidae Trachytheriinae and Interatheriidae Interatheriinae, which are rather hypsodont but not hypselodont (Hitz et al., 2000; Reguero et al., 2002, Reguero and Castro, 2004).

The body size of Medistylus dorsatus falls in the range-size category 1 (="rabbit size") of Janis (1997). Medistylus dorsatus co-occurred in the Deseadan with other typotheres that had similar or slightly larger body size like Plagiarthrus clivus Ameghino, 1897 (Interatheriidae), Prohegetotherium sculptum Ameghino, 1897 (Hegetotheriidae), and Archaeohyrax patagonicus Ameghino, 1897 (Archaeohyracidae).

In ungulate species, the relative width of the muzzle is related to the degree of selectivity in the diet. It is obvious that the shape of the premaxillae reflects the dietary strategy adopted by these ungulates. The expectation is that grazers would have a relatively broader muzzle than browsers or mixed feeders, and that within grazers short-grass grazers would have relatively broader muzzles than tall-grass grazers. Janis and Ehrhardt (1988), Solounias and Moelleken (1993), and Dompierre and Churcher (1996) have demonstrated that premaxillary shape correlates with dietary strategy in ungulates. The PSI value $(87 \%)$ of Medistylus dorsatus (Fig. 3) is more similar to that of the grazers estimated for modern and extinct camelid species by Dompierre and Churcher (1996).

Medistylus dorsatus was closely related to and contemporaneous with Prosotherium garzoni, suggesting that Oligocene habitatpartitioning was considerably finer among medium rodent-like 
mammals than seen in modern Patagonia. The selective foodcropping mechanism of the upper incisors (with oblique implantation), a long diastema, and very high-crowned molars (hypselodont) are likely reflective of some aspect of Medistylus dorsatus feeding behavior linked to grasslands. The small size of Medistylus suggests that it could feed close to the ground, incorporating enough abrasive grit in its diet, and hence would have exceedingly hypsodont cheek teeth. The body size of Medistylus dorsatus matches very well with the Patagonian caviomorph Dolichotis patagonum.

In Medistylus and Prosotherium the morphology of the relatively broad muzzle and the great hypsodonty, together with the evergrowing upper incisors, the presence of a large diastema, and the small body size indicate that they would have been the most well-adapted mammals for a grazing lifestyle that lived during the Deseadan SALMA in Patagonia.

The morphology of the masseter also permits the reconstruction of the diet of some ungulates (Solounias et al., 1995). In Medistylus, the zygomatic arch is well expanded (Fig. 2C), laterally forming a conspicuous, flattened plate (zygomatic plate of Patterson, 1934), and the area of the masseter terminates at the end of the zygomatic bone in the middle of the zygomatic arch. There is a great maxillary fossa that serves as insertion of the masseter muscles ( $m$ superficialis and profundus). This fossa is located anteriorly on the skull and occupies a substantial region of the maxilla. The masseteric area is similar to that of grazing ruminants, but no masseter superficialis protrusion is present in Medistylus dorsatus as it is seen in other grazing ungulates like the bovids (Solounias et al., 1995).

Herbivores living in open habitats have a greater tendency to be hypsodont, regardless of a food preference, than those living in closed habitats, mainly because of the greater amount of sand and dust adhering to the plants and acting "as an effective abrasive agent" (Stirton, 1947:36). Janis (1988) pointed out that hypsodonty occurs in herbivores feeding on any type of low vegetation that would be subjected to abrasive dust and grit coverage. For Pascual and Ortiz Jaureguizar (1990), the precocious hypsodonty in South American ungulates was an effective response to abrasive volcanic ash that had dusted the plants. Additionally, sedimentological data and phytolith stratigraphy of the Sarmiento Formation at Gran Barranca, Chubut Province, suggest that the dominance of phytoliths in Patagonia is in agreement with the increased pace of ungulate hypsodonty since the Late Eocene (Mazzoni, 1979; Kay et al., 1999). The pyroclastic-derived sediments of the Sarmiento Formation are characterized by reworked aeolian and ash-fall deposits (Mazzoni, 1985; Barreda and Bellosi, 2003). In addition to documenting important changes in hypsodonty on a faunal level, Tinguirirican faunas have clarified other aspects of dental evolution in various notoungulate clades (Flynn et al., 2003). A dramatic jump in hypsodonty (without the attainment of hypselodonty) is synchronous across several lineages of typotheres (interatheriids, archaeohyracids) by the Tinguirirican. However, hypselodonty (i.e., "euhypsodonty"), in contrast, appears to have originated among notoungulates in two pulses: by the Divisaderan (late Eocene) in hegetotheriids and mesotheriids, and by the Deseadan (late Oligocene) in interatheriids and toxodontids. So, the evolutionary acquisition of evergrowing tooth crowns in pachyrukhines seems to have occurred during the early Oligocene and apparently it was abrupt. Conversely, the evolutionary acquisition of this characteristic in Hegetotheriinae was sufficiently slow to be detected in the Late Eocene/Miocene stratigraphic record of Argentina. This stratigraphic record of the Hegetotheriinae documents an increase in cheek-tooth crown height from Divisaderan (late Eocene?) Ethegotherium carettei (Minoprio, 1947) to Deseadan (late Oligocene) Prohegetotherium sculptum to Colhuehuapian/Santacrucian (early/middle Miocene) $\mathrm{He}$ getotherium mirabile Ameghino, 1887a (Reguero and Cerdeño, 2005).
The occurrence of three fully hypsodont genera of Pachyrukhinae in the Deseadan of Patagonia is the first and most diverse radiation of the rodentlike notoungulates, suggesting a paleoenvironment of open areas, grasslands, and savannas in a temperate climate (Pascual and Ortiz Jaureguizar, 1990). However, isotopic analysis of teeth of Deseadan herbivores provides an overwhelming $\mathrm{C}_{3}$ signal for the paleovegetation (MacFadden et al., 1996). Therefore, the probable spread of grasslands during the Early Eocene at Río Turbio, Santa Cruz Province (Berry, 1925), occurred in a regime that lacked $\mathrm{C}_{4}$ photosynthesis. It is possible a paleoenvironmental reconstruction of the Deseadan vegetation in Patagonia with $\mathrm{C}_{3}$ grasses growing only under trees, with no open grasslands, only small clearings, lake margins, and meadows.

The Deseadan ungulate fauna of Patagonia is noteworthy for its high diversity of sympatric hypselodont small/medium-sized rodentlike notoungulates (typotheres) with apparently similar ecological requirements (Archaeohyracidae, Interatheriidae, Hegetotheriidae, and Mesotheriidae). However, this high diversity seems to be associated with a need for these notoungulates to partition the available plant resources. As in modern African Bovidae, resource partitioning seems to occur on at least three levels, including choice of primary food, habitat preference, and feedingheight preference (Jarman, 1974). However, it is possible that trophic niche overlapping between typothere species might occur as it does nowadays in Patagonia between Dolichotis patagonum and the European hare (Bonino et al., 1997).

The "rodentlike" morphology of the skull and postcranial skeleton of two pachyrukhines, the early-middle Miocene Pachyrukhos and the late Miocene-Pliocene Paedotherium, has been highlighted since the earliest studies of Ameghino (1889). However, other authors suggested a "rabbit-like" way of life of these genera based particularly on the architecture of the skull, i.e., slender rostrum with a long diastema, the facial area perforated by a network of foramina, very high-crowned cheekteeth, large prominent orbits, and the great posterior depth of the mandible (Sinclair, 1909; Scott, 1937; Cifelli, 1985). Also, in Pachyrukhos moyanoi Ameghino, 1885 of the Santacrucian SALMA (middle Miocene), the plantigrade hind limb closely resembles that of a hare. In fact, Pachyrukhos apparently was adapted to jump based on the great length and strength of the hind limb and inner digits. This specialization is not evident in Paedotherium, the last representative of the subfamily, since the metapodials in this genus possess a better-developed distal keel favoring an unguligrade locomotion rather than jumping (Kraglievich, 1926). Based on a morphometric analysis, Elissamburu (2004) pointed out that Paedotherium is better prepared to develop force (humerus robustness, olecranon proportion and ulna robustness) rather than speed, and a fossorial habit can be inferred for this genus. According to Cerdeño and Bond (1998), Paedotherium might have utilized burrows made by itself or by other fossorial mammals, since its remains are frequently found, together with the ctenomyine rodent Actenomys, infilling cavities of the Chapadmalal Formation (early Pliocene) (Genise, 1989).

Although pachyrukhines are the most frequently encountered taxa at many other Deseadan localities of Patagonia, they are absent from the low and middle latitude localities at Salla (Bolivia) and Fray Bentos (Uruguay). The absence of Pachyrukhinae in the Deseadan of Bolivia and Uruguay can be attributed to ecological factors. Since Salla $\left(17^{\circ} \mathrm{S}\right)$ and Fray Bentos $\left(34^{\circ} \mathrm{S}\right)$ are at a significantly lower latitude than the classical Deseadan localities of Patagonia (between $44^{\circ}$ and $47^{\circ} \mathrm{S}$ ), one might consider the possibility there was a regional effect; that is, conditions were more favorable for pachyrukhines in higher latitudes than the more tropical latitude of Salla and Fray Bentos. Their absence in these latitudes is likely due to local conditions that were less favorable to other high-crowned ungulate taxa (typotheres and notohippids) and to lower-crowned herbivores. The presence of less hypsodont typotheres in Salla (Reguero and Cerdeño, 2001, 2005) and Fray 
Bentos (Reguero et al., 1998, 2002) supports this statement and suggests more closed environments in these areas and the presence of fewer abrasives in the vegetation.

\section{CONCLUSIONS}

We describe new and more nearly complete material, a very well-preserved skull, of Medistylus dorsatus from the Deseadan SALMA of Cabeza Blanca, Chubut province, Argentina. We confirm that this species pertains to the Hegetotheriidae Pachyrukhinae. Originally, the taxon was based on three isolated upper molars, now reported lost.

The Deseadan Pachyrukhinae provide evidence of a previously unsuspected early diversity of these rodentlike notoungulates in Patagonia.

Functionally, the suite of cranial and dental characters in Medistylus is best interpreted as adaptations for selective grazing. In this respect, Medistylus shows a convergent resemblance to the modern grazing rodent Dolichotis patagonum.

\section{ACKNOWLEDGMENTS}

J. Fleagle (Stony Brook University) found the specimen MPEF-PV 693. We are very grateful to D. Croft for critical reading of the manuscript. We thank R. Kay, R. Madden, and M. G. Vucetich for permission to use, for comparison and description, specimens from Las Cascadas and Cabeza Blanca localities (their field research was supported by the National Science Foundation). Finally we thank A. Venter (owner of "Estancia El Molino," Departamento Escalante, Chubut) and his family and R. Taylor (Centro Nacional Patagónico) for helping and attending in the field, and L. Reiner (Museo Paleontológico Egidio Feruglio) for preparing the specimen MPEF-PV 693. Museum studies of MAR were funded by M. O. Woodburne (from a US-NSF Grant), the "Vertebrate Paleontology Visitor's Research Fellowship" of the Florida Museum of Natural History, Gainesville (B. MacFadden), and the Consejo Nacional de Investigaciones Científicas y Técnicas (CONICET). The studies of MTD are supported in different ways by The Thomas J. Dee Fellowship Fund (Field Museum of Natural History, Chicago), Collection Study Grant (American Museum of Natural History, New York), and CONICET Grant PIP02628. D. Croft and M. Bond are thanked for careful and constructive reviews of the manuscript.

\section{REFERENCES}

Ameghino, F. 1885. Nuevos restos de mamíferos fósiles oligocenos recogidos por el Profesor Pedro Scalabrini y pertenecientes al Museo Provincial de la ciudad de Paraná. Boletín de la Academia Nacional de Ciencias de Córdoba, 8:5-207.

Ameghino, F. 1887a. Enumeración sistemática de las especies de mamíferos fósiles coleccionados por Carlos Ameghino en los terrenos eocenos de $\mathrm{Pa}$ tagonia austral y depositados en el Museo La Plata. Boletín del Museo La Plata, 1, 26 p. (from reprint)

AMEGHINO, F. 1887b. Apuntes preliminares sobre algunos mamíferos extinguidos del yacimiento de "Monte Hermoso" existentes en el "Museo La Plata." Boletín del Museo La Plata, 1, 20 p. (from reprint)

AMEGHINO, F. 1887c. Observaciones generales sobre el orden de mamíferos extinguidos Sud-Americanos llamados toxodontes (Toxodontia) y sinopsis de los géneros y especies hasta ahora conocidos. Anales del Museo La Plata, (Entrega especial, 1936), 66 p.

Ameghino, F. 1888. Lista de las especie de mamíferos fósiles del Mioceno superior de Monte-Hermoso, hasta ahora conocidas. P.E. Coni, Buenos Aires, $21 \mathrm{p}$

Ameghino, F. 1889. Contribución al conocimiento de los mamíferos fósiles de la República Argentina. Actas de la Academia Nacional de Ciencias de Córdoba, 8:1-207.

AmeGHino, F. 1894. Enumération synoptique des espèces de mammifères fossiles des formations éocènes de Patagonie. Boletín de la Academia Nacional de Ciencias de Córdoba, 13:259-445.

Ameghino, F. 1897. Mammifères crétacés de l'Argentine. (Deuxième contribution à la connaissance de la faune mammalogique des couches à Pyrotherium). Boletín del Instituto Geográfico Argentino, 18:405-521.

AmEGHino, F. 1903. Nuevas especies de mamíferos cretáceos y terciarios de la República Argentina. Anales de la Sociedad Científica Argentina, 56: $193-208$

AMEGHINO, F. 1904. Rechérchès de morphologie phylogénétique sur les molaires supérieures des ongulés. Anales del Museo Nacional de Buenos Aires, 9 (ser. 3a, 3), 541 p.

BERRY, E. W. 1925. Miocene flora from Patagonia. John Hopkins University, Studies in Geology, 6:183-233.
BARREDA, V. AND E. Bellosi. 2003. Ecosistemas terrestres del Mioceno temprano de la Patagonia central, Argentina: Primeros avances. Revista del Museo Argentino de Ciencias Naturales, n.s., 5(2):125-134.

Bond, M. 1986. Los ungulados fósiles de Argentina: evolución y paleoambientes. IV Congreso Argentino de Paleontología y Bioestratigrafía, Mendoza, Actas 2:173-185.

Bonino, N., A. Sbriller, M. M. ManaCorda, And F. Larosa. 1997. Food partitioning between the mara (Dolichotis patagonum) and the introduced hare (Lepus europaeus) in the Monte Desert, Argentina. Studia Neotropica Fauna and Environment, 32:129-134.

CASTRO, P. 2001. Los Hegetotheriidae (Mammalia: $†$ Notoungulata: Hegetotheria) del Paleógeno de Patagonia, Argentina: sistemática, filogenia y paleoecología. A thesis presented to the graduate school of the Universidad Nacional of Patagonia "San Juan Bosco," Chubut.

CERdEÑo, E. AND M. Bond. 1998. Taxonomic revision and phylogeny of Paedotherium and Tremacyllus (Pachyrukhinae, Hegetotheriidae, Notoungulata) from the Late Miocene to the Pleistocene of Argentina. Journal of Vertebrate Paleontology, 18:799-811.

CiFELli, R. L. 1985. South American ungulate evolution and extinction. The great American biotic interchange, p. 249-266. In F. G. Stehli and S. D. Webb (eds.), The Great American Biotic Interchange. Plenum Press, New York.

CifElli, R. L. 1993. The phylogeny of the native South American Ungulates. Mammal phylogeny. Placentals, p. 195-216. In F. S. Szalay, M. J. Novacek, and M. C. McKenna (eds.), Mammal Phylogeny: Placentals. Springer-Verlag, New York.

CRofT, D. A. 1999. Placentals: South American ungulates, p. 890-906. In R. Singer (ed.), The Encyclopedia of Paleontology. Fitzroy-Dearborn Publishers, Chicago, Illinois.

Croft, D. A. 2000. Archaeohyracidae (Mammalia, Notoungulata) from the Tinguiririca Fauna, central Chile, and the evolution and paleoecology of South American mammalian herbivores. Unpublished Ph.D. dissertation, The University of Chicago.

Croft, D. A. And F. AnAyA. 2004. A new hegetotheriid from the middle Miocene of Quebrada Honda, Bolivia, and a phylogeny of the Hegetotheriidae. Journal of Vertebrate Paleontology, 24(3 Suppl.):48-49A.

CROFT, D. A., J. J. FlynN, AND A. R. Wyss. 2004. Notoungulata and Litopterna of the early Miocene Chucal Fauna, northern Chile. Fieldiana: Geology (New Series), 50:1-52.

DOMPIERRE, H. AND C. S. CHURCHER. 1996. Premaxillary shape as an indicator of the diet of seven extinct Late Cenozoic New World camels. Journal of Vertebrate Paleontology, 16(1):141-148.

Dozo, M. T. 1997. Paleoneurología de Dolicavia minuscula (Rodentia, Caviidae) y Paedotherium insigne (Notoungulata, Hegetotheriidae) del Plioceno de Buenos Aires, Argentina. Ameghiniana, 34(4):427-435.

Dozo, M. T., M. A. Reguero, AND E. Cerdeño. 2000. Medistylus dorsatus (Ameghino, 1903), un Hegetotheriidae Pachyrukhinae (Mammalia, Notoungulata) del Deseadense de la provincia de Chubut, Argentina. Ameghiniana, Resúmenes, 37(4):24R.

Elissamburu, A. 2004. Análisis morfométrico y morfofuncional del esqueleto apendicular de Paedotherium (Mammalia, Notoungulata). Ameghiniana, 41(3):363-380.

Flynn, J. J., A. R. Wyss, D. A. Croft, And R. Charrier. 2003. The Tinguiririca Fauna, Chile: biochronology, paleoecology, biogeography, and a new earliest Oligocene South American Land Mammal "Age." Palaeogeography, Palaeoclimatology, Palaeoecology, 195:229-259.

GENISE, J. F. 1989. Las cuevas de Actenomys (Rodentia, Octodontidae) de la Formación Chapadmalal (Plioceno superior de Mar del Plata y Miramar (provincia de Buenos Aires). Ameghiniana, 26:33-42.

Hitz, R., M. A. Reguero, A. R. Wyss, and J. J. Flynn. 2000. New interatheriines (Interatheriidae, Notoungulata) from the Paleogene of central Chile and southern Argentina. Fieldiana: Geology (New Series), 42:1-26.

JANIS, C. M. 1988. An estimation of tooth volume and hypsodonty indices in ungulates mammals, and the correlations of these factors with dietary preference, p. 367-387. In D. Russelll, J. P. Santoro, and D. Sigogneau-Russell (eds.), Teeth Revisited: Proceedings of the VIIth International Symposium on Dental Morphology. Mémoires de Muséum national d'histoire Naturelle (serie C), 53. Editions du Muséum, Paris.

JANIS, C. M. 1995. Correlations between craniodental morphology and feeding behavior in ungulates: reciprocal illumination between living and fossil taxa, p. 76-98. In J. J. Thomason (ed.), Functional Morphology in Vertebrate Paleontology. Cambridge University Press, New York.

JANIS, C. M. 1997. Ungulate teeth, diets, and climatic changes at the Eocene/ Oligocene boundary. Zoology, 100(3):203-220.

JANIS, C. M. AND D. EHRHARDT. 1988. Correlation of relative muzzle width and relative incisor width with dietary preference in ungulates. Zoological Journal of the Linnean Society, 92:267-284.

JANIS, C. M., J. DAMUTH, AND J. M. THEODOR. 2000. Miocene ungulates and 
terrestrial primary productivity: Where have all the browsers gone? Proceedings of the National Academy of Sciences of the United States of America, 97(14):7899-7904.

JARMAN, P. J. 1974. The social organization of antelopes in relation to their ecology. Behaviour, 48:213-267.

Kay, R., R. H. Madden, M. G. Vucetich, A. A. Carlini, M. M. Mazzoni, G. H. Re, M. HeIZLER, AND H. SANDEMAN. 1999. Revised geochronology of the Casamayoran South American Land Mammal Age: Climatic and biotic implications. Proceedings of the National Academy of Sciences of the United States of America, 96:13235-13240.

Kohn, M. J., J. A. Josef, R. Madden, R. Kay, G. Vucetich, and A. A. CARLINI. 2004. Climate stability across the Eocene-Oligocene transition, southern Argentina. Geology, 32:621-624.

KRAGLIEVICH, L. 1926. Sobre el conducto humeral en las vizcachas y paquirucos chapadmalenses con descripción del Paedotherium imperforatum. Anales del Museo de Historia Natural Bernardino Rivadavia, 34:45-88.

Kraglievich, L. 1934. La antigüedad pliocena de las faunas de Monte Hermoso y Chapadmalal, deducidas de su comparación con las que le precedieron y sucedieron. Imprenta El Siglo Ilustrado. Montevideo Obras Completas, 3:293-433.

LiNNAEUS, C. 1758. Systema Naturae per regna tria Naturae, secumdum Classes, Ordines, Genera, Species cum Characteribus, Differentiis, Synonymis, Locis. Volume 1 (Tenth edition) L. Salvii, Uppsala, 824 p.

Loomis, F. B. 1914. The Deseado Formation of Patagonia. The Rumford Press, Concord, New Hampshire, 232 p.

MacFadden, B. J., T. E. Cerling, and J. Prado. 1996. Cenozoic terrestrial ecosystem evolution in Argentina: Evidence from carbon isotopes of fossil mammal teeth. Palaios, 11:319-327.

MARSHALL, L. G. AND R. L. CIFELLI. 1989. Analysis of changing diversity patterns in Cenozoic land mammal age faunas, South America. Palaeovertebrata, 19:169-210.

MAZZONI, M. M. 1979. Contribución al conocimiento petrográfico de la Formación Sarmiento. Barranca sur del lago Colhue Huapi, provincia de Chubut. Revista de la Asociación Argentina de Mineralogía, Petrología y Sedimentología, 10(3-4):33-53.

Mazzoni, M. M. 1985. La Formación Sarmiento y el vulcanismo paleógeno. Revista de la Asociación Geológica Argentina, 40(1-2):60-68.

McKennA, M. C. AND S. K. Bell. 1997. Classification of mammals above the species level. New York: Columbia University Press. p. 1-631.

MinOPRIO, J. L. 1947. Fósiles de la Formación del Divisadero Largo. Anales de la Sociedad Científica Argentina, 146:365-378.

Moreno, F. P. 1882. Patagonia, resto de un antiguo continente hoy sumergido. Anales de la Sociedad Científica Argentina, 14:97-131.

PAtTERSON, B. 1934. Trachytherus, a typotherid from the Deseado beds of Patagonia. Field Museum of Natural History, Geological Series, 6:91-111.

PATTERSON, B. 1952. Un nuevo y extraordinario marsupial Deseadiano. Museo Municipal de Ciencias Naturales y Tradicional de Mar del Plata, revista, 1(1):9-44.

Patterson, B. AND R. PAscual. 1972. The fossil mammal fauna of South America, p. 247-309. In A. Keast, F. C. Erk, and B. Glass (eds.), Evolution, Mammals and Southern Continents. University of New York State Press, Albany.

PASCUAL, R. AND E. ORTIZ JAUREGUIZAR. 1990. Evolving climates and mammal fauna in Cenozoic South America. Journal of Human Evolution, 19: 23-60.

Pascual, R., A. A. Carlini, M. Bond, and F. J. Goin. 2002. Mamíferos cenozoicos, p. 533-544. In M. J. Haller (ed.), Geología y Recursos Naturales de Santa Cruz. Relatorio del XV Congreso Geológico Argentino, El Calafate.

Pérez-BARberia, F. J. AND I. J. Gordon. 2001. Relationships between oral morphology and feeding style in the Ungulata: A phylogenetically controlled evaluation. Proceedings of the Royal Society of London, 268:10211030.

Reguero, M. A. 1993. Los Typotheria y Hegetotheria (Mammalia, Notoungulata) eocenos de la localidad Cañadón Blanco, Chubut. Ameghiniana, $30(3): 336$
REGUERO, M.A. 1999. El problema de las relaciones sistemáticas y filogenéticas de los Typotheria y Hegetotheria (Mammalia, †Notoungulata): análisis de los taxones de Patagonia de la Edad-mamífero Deseadense (Oligoceno). Ph.D. dissertation, Departamento de Ciencias Biológicas, Facultad de Ciencias Exactas y Naturales, Universidad de Buenos Aires, Buenos Aires.

Reguero, M. A. AND P. CASTro. 2004. Un nuevo Trachytheriinae (Mammalia, †Notoungulata) del Deseadense (Oligoceno tardío) de Patagonia, $\mathrm{Ar}-$ gentina: implicancias en la filogenia, biogeografía y bioestratigrafía de los Mesotheriidae. Revista Geológica de Chile, 31(1):45-64.

Reguero, M. A. AND E. CerdeÑo. 2001. New Hegetotheriidae (Notoungulata) from the Deseadan (Late Oligocene) of Salla (Bolivia). Ameghiniana, suplemento, resúmenes, 38(4):17R.

Reguero, M. A. ANd E. Cerdeño. 2005. New late Oligocene Hegetotheriidae (Mammalia, Notoungulata) from Salla, Bolivia. Journal of Vertebrate Paleontology, 25(3):674-684.

Reguero, M. A., M. Ubilla, and D. Perea. 1998. A new species of Archaeohyracidae (Mammalia, Notoungulata) from Fray Bentos Formation (Deseadan) of Uruguay. Acta Geológica Lilloana, 18:178-179.

Reguero, M. A., M. Ubilla, and D. Perea. 2002. A new species of Eopachyrucos (Mammalia, Notoungulata, Interatheriidae) from the late Oligocene of Uruguay. Journal of Vertebrate Paleontology, 23(2):445-457.

REIG, O. A. 1981. Teoría del origen y desarrollo de la fauna de mamíferos de América del Sur. Monographiae Naturae, 1. 162p.

Rотн, S. 1903. Noticias preliminares sobre algunos nuevos mamíferos fósiles. Revista del Museo de La Plata, p. 1-26.

ScOTT, W. B. 1937. A history of land mammals in the Western Hemisphere (second edition). Macmillan, New York, $786 \mathrm{p}$.

SHOCKEY, B. J. 1997. Two new notoungulates (Family Notohippidae) from the Salla beds of Bolivia (Deseadan: Late Oligocene): systematics and functional morphology. Journal of Vertebrate Paleontology, 17(3):584-599.

SiMPSON, G. G. 1945a. The principles of classification and a classification of mammals. Bulletin of the American Museum of Natural History, 85:1-350.

SIMPSON, G. G. 1945b. A Deseado hegetothere from Patagonia. American Journal of Science, 243:550-564.

SINCLAIR, W. J. 1909. Mammalia of the Santa Cruz beds. I. Typotheria. Reports of the Princeton University Expeditions to Patagonia,1896-1899, 6: $1-110$.

Solounias, N. AND S. M. C. Moelleken. 1993. Dietary adaptation of some extinct ruminants determined by premaxillary shape. Journal of Mammalogy, 74(4):1059-1071.

Solounias, N., S. M. C. Moelleken, and J. M. Plavcan. 1995. Predicting the diet of extinct bovids using masseteric morphology. Journal of Vertebrate Paleontology, 15(4):795-805.

SpalletTi, L. AND M. MAZZONI. 1979. Estratigrafía de la Formación Sarmiento en la Barranca Sur del Lago Colhue Huapi, Provincia de Chubut. Asociación Geológica Argentina, Revista, 34(4):271-281.

STIRTON, R. A. 1947. Observations on evolutionary rates of hypsodonty. Evolution, 1:32-41.

StiRTON, R. A. 1952. Medistylus, new name for Phanophilus Ameghino, not Sharp. Journal of Paleontology, 26(3):351.

StRÖMBERG, C. A. E. 2002. The origin and spread of grass-dominated ecosystems in the late Tertiary of North America: preliminary results concerning the evolution of hypsodonty. Palaeogeography, Palaeoclimatology, $\mathrm{Pa}-$ laeoecology, 177:59-75.

WiLLIAMS, S. H. AND R. F. KAY. 2001. A comparative test of adaptive explanations for hypsodonty in ungulates and rodents. Journal of Mammalian Evolution, 8(3):207-229.

Zimmermann, E. A. W., von. 1778-1783. Geographische Geschichte des Menschen, und der allgemein verbreiteten vierfüssigen Thiere, nebsit einer hieher gehörigen zoologischen Weltkarte. Volume 2. Geographische Geschichte des Menschen, und der vierfüssigen Thiere Zweiter Band. Enthält ein vollständiges Verzeichniss aller bekannten Quadrupeden. Weygandschen Buchhandlung, Leipzig.

ZitTel, K. A., Von. 1893. Handbuch der Palaeontologie. Abteilung I. Palaeozoologie. Band IV, Vertebrata (Mammalia). Munich, R. Oldenbourg, xi $+799 \mathrm{p}$.

ACCEPTED 23 August 2006 